\title{
Impact Assessment of Atmospheric Pollutants Emissions from Mining Operations at Ghana Manganese Company Ltd.*
}

\author{
${ }^{1}$ N. Amegbey, ${ }^{1}$ B. O. Afum, ${ }^{1}$ S. Ndur and ${ }^{2}$ E. Coffie-Anum \\ ${ }^{1}$ University of Mines and Technology, P.O. Box 237, Tarkwa, Ghana \\ ${ }^{2}$ Ghana Manganese Company Ltd., Tarkwa, Ghana
}

Amegbey, N., Afum, B. O., Ndur, S., and Coffie-Anum, E., (2016), "Impact Assessment of Atmospheric Pollutants Emissions from Mining Operations at Ghana Managanese Company Ltd.", Ghana Mining Journal, Vol. 16, No. 2, pp. 65 - 72.

\begin{abstract}
Atmospheric pollutants diffusion study was conducted around the operational sites and immediate neighbouring communities of Ghana Manganese Company (GMC). The pollutants are emitted by sources associated with the main operations and activities of the mine including on-bench rock drilling and blasting, material excavation and hauling, vehicular movements and mine machinery exhaust emissions, as well as crushing of blasted rocks. Methodologies involving computerised dispersion modelling was used to estimate near-field ambient pollutant impacts on neighbouring TarkwaBanso community, at $400 \mathrm{~m}$ from the Mine's nearest operational site (Pit C North). The community is located in the dispersive fan of North to the East-South-Eastern part of the mine site. Measured airborne particulates (PM $\mathrm{PM}_{10}$ and TSP) concentrations in the Tarkwa-Banso community were below Ghana EPA's permissible limits of $70 \mu \mathrm{g} / \mathrm{m}^{3}$ and $150 \mu \mathrm{g} / \mathrm{m}^{3}$ respectively. The predicted monthly concentrations of the airborne particulates ( $\mathrm{PM}_{10}$ and TSP) at $400 \mathrm{~m}$ buffer from the crushing plant were greatly lower than the permissible regulatory limits. With effective dust mitigation measures, the predicted $\mathrm{PM}_{10}$ and TSP dust concentrations emanating from drilling, blasting, loading and hauling activities at Pit C North were also generally lower than the regulatory requirement. All the predicted monthly concentrations of $\mathrm{NO}_{\mathrm{x}}$ and $\mathrm{SO}_{2}$ at the $400 \mathrm{~m}$ buffer from Pit C North were significantly lower than the allowable regulatory requirement of $60 \mu \mathrm{g} / \mathrm{m}^{3}$ and 100 $\mu \mathrm{g} / \mathrm{m}^{3}$ respectively. The study indicates that, the operation of the crushing plant together with the general mining operations at Pit $\mathrm{C}$ North in the mine has no significant impact on Tarkwa-Banso community.
\end{abstract}

Keywords: Impacts, Particulates Matter, Concentration Levels, Environment, Prediction

\section{Introduction}

The main operations of the Ghana Manganese Company (GMC) involve mining and hauling of blasted material to its on-site processing plants for eventual crushing. The operations fall within Tarkwa-Banso and Nsuta communities in the Tarkwa-Nsuaem Municipality (TNM), located in the south-western part of Ghana. The Company wishes to develop the northern extension of its Pit C North. Tarkwa-Banso community, located in the North and East-South-Eastern part of the Mine's site is of much importance due to its proximity to the Pit $\mathrm{C}$ North. The population of the community is estimated around 115,000 with majority of its inhabitants being farmers.

Pit blasting would be conducted in the day according to the Ghanaian mining regulations. The proposed Pit $\mathrm{C}$ North will be mined by conventional open pit mining method utilising drill rigs, excavators, loaders and haul trucks in a fleet. Blasted ore will be hauled with 100 tonne truck and stockpiled at the carbonate crushing plant for processing whilst waste materials from the pit will be hauled directly to the Pit $\mathrm{C}$ North waste dump (GMC-EIS, 2012). The carbonate crushing plant is located about $1.8 \mathrm{~km}$ from the $400 \mathrm{~m}$ buffer of Pit C North pit crest into Tarkwa-Banso Township. At the carbonate plant, dry crushing and classification of the carbonate ore into fines, logs and lumpy products are conducted.

Management of GMC is required to show that the $400 \mathrm{~m}$ buffer zone from the crest of Pit C North is sufficient and guarantees that the air quality (particulates and gases) falls within the national guidelines.

The paper is an atmospheric pollutants diffusion study that was conducted around the operational sites of GMC and its immediate Tarkwa-Banso community. The aim was to predict the possible atmospheric impacts of mining during the development of Pit $\mathrm{C}$ North. The main air pollutants considered in this study are Particulates Matter of aerodynamic size $10 \mu \mathrm{m}$ and below $\left(\mathrm{PM}_{10}\right)$, Total Suspended Particulates (TSP), Sulphur Dioxide $\left(\mathrm{SO}_{2}\right)$, and Oxides of Nitrogen $\left(\mathrm{NO}_{\mathrm{x}}\right)$.

\subsection{Location and Climate of Study Area}

The Ghana Manganese Company (GMC) is about $304 \mathrm{~km}$ drive from Accra and about $63 \mathrm{~km}$ drive from the Western Regional Capital, Takoradi, Ghana. The location of the GMC site is shown in Fig. 1. The site lies within a tropical humid 
rainforest zone. The rainfall pattern (from January 2009 to December 2013) on the site, shown in Fig. 2 , averaged $117.3 \mathrm{~mm}$ per month. This indicates a high rainfall zone.

There are two main rainfall seasons on the mine site; the period May to July with rainfall values from 179.2 to $195.9 \mathrm{~mm}$ and again the period September to December with rainfall values ranging from 141.8 to $179.9 \mathrm{~mm}$. The maximum rainfall value was recorded in June as $296.5 \mathrm{~mm}$, followed by $210.7 \mathrm{~mm}$ in October and $195.9 \mathrm{~mm}$ in July (Amegbey and Afum, 2014).

The dry seasons on the mine site were noted in December and January with respective rainfall values $54.3 \mathrm{~mm}$ and $62.97 \mathrm{~mm}$, followed by August and February with rainfall values of 78.9 $\mathrm{mm}$ and $80.3 \mathrm{~mm}$ respectively.

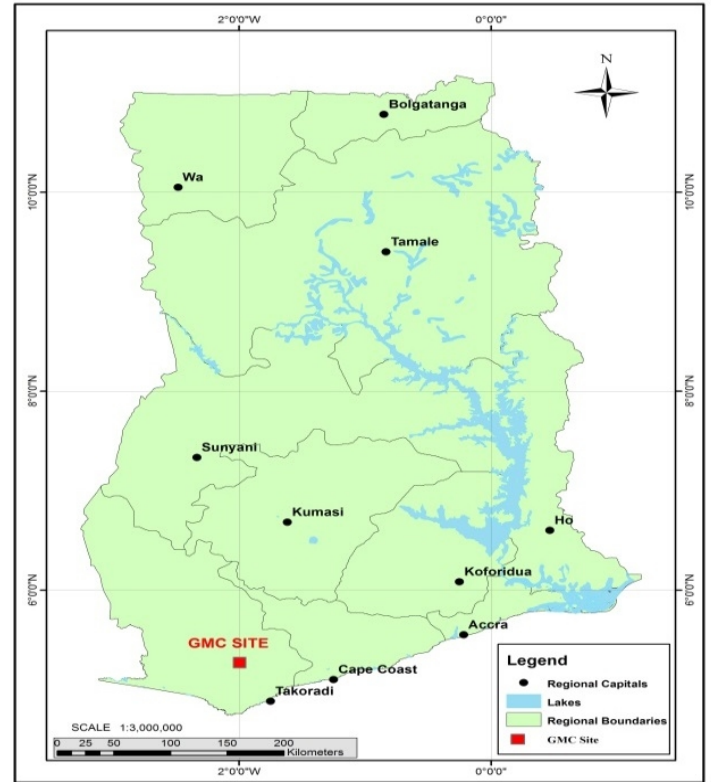

Fig. 1 Map Showing GMC Site (Source: Amegbey and Afum, 2016)

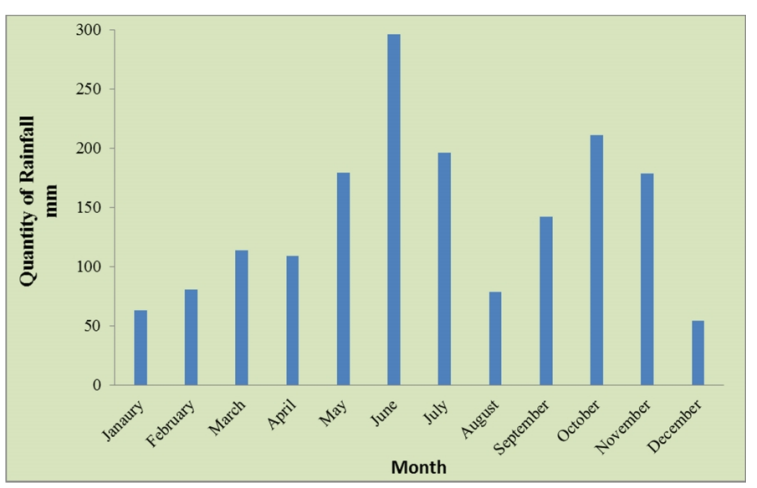

Fig. 2 Monthly Rainfall Variations on GMC Site (January 2009 to December 2013)

\subsection{Wind Movements and Air Quality Monitoring}

Air pollutants concentration levels are dispersed according to the direction of wind movement. GMC undertakes regular monitoring of airborne particulates on its operational site and the TarkwaBanso community. The Osiris Airborne Particulates Monitors are used for such measurements. An annual Windrose generated for GMC site for the period January 2013 to December 2013 superimposed on GMC site map shows the locations of the monitoring stations, the Pit C North and the Tarkwa-Banso community (Fig. 3). It can be seen that, Tarkwa-Banso is located in the lateral dispersive fan of North (N) and East South-East (ESE) of Pit C North.

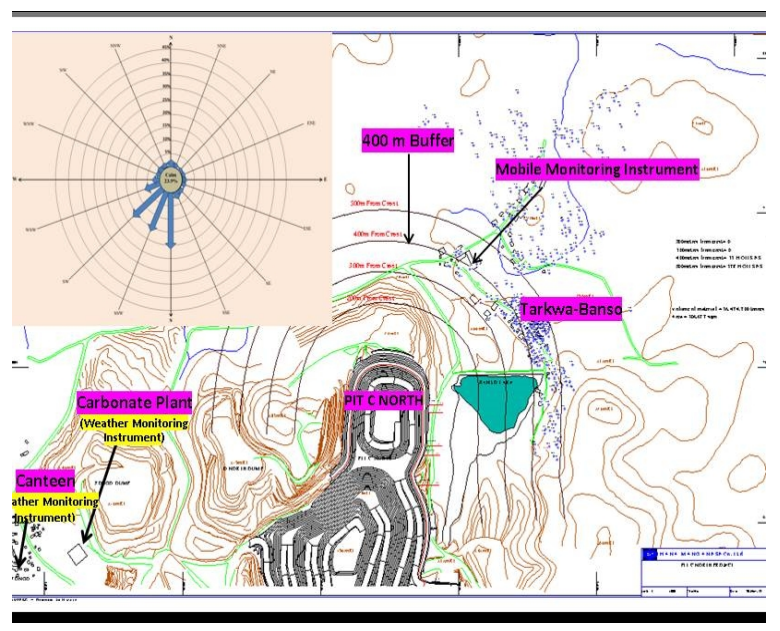

Fig. 3 Wind Heading in relation to various Landmarks on GMC Site

Generally, the statistics of the resultant wind on GMC site is characterised by dominant south winds with average wind speed of $0.71 \mathrm{~m} / \mathrm{s}$ and a calm frequency of $23.9 \%$. Table 1 shows the average wind speeds and percentage periods in the year 2013 for wind heading on GMC site.

Table 1 General Wind Heading Data for the Year 2013 on GMC Site

\begin{tabular}{|l|c|c|}
\hline $\begin{array}{c}\text { Wind } \\
\text { Heading }\end{array}$ & $\begin{array}{c}\text { Mean Wind } \\
\text { Speed (m/s) }\end{array}$ & $\begin{array}{c}\text { Percentage of } \\
\text { Year 2013 (\%) }\end{array}$ \\
\hline N & 0.37 & 2.9 \\
\hline NNE & 0.44 & 1.9 \\
\hline NE & 0.50 & 0.5 \\
\hline ENE & 0.20 & 0.4 \\
\hline E & 0.52 & 1.2 \\
\hline ESE & 0.63 & 1.1 \\
\hline SE & 0.49 & 1.2 \\
\hline SSE & 0.79 & 3.2 \\
\hline S & 0.71 & 20.1 \\
\hline SSW & 0.81 & 16.1 \\
\hline SW & 0.69 & 16.8 \\
\hline WSW & 0.62 & 5.6 \\
\hline W & 0.42 & 1.8 \\
\hline WNW & 0.40 & 1.1 \\
\hline NW & 0.32 & 1.3 \\
\hline NNW & 0.15 & 1.0 \\
\hline Calm & 0.00 & 23.9 \\
\hline
\end{tabular}


The monthly statistics of wind heading in the direction of Tarkwa-Banso community is shown in Table 2. It can be seen that January and April are the highest periods in the year that wind significantly blows from GMC site towards the community. Per Table 2, any wind bearing air pollutants blowing from GMC has the tendency to impact the community negatively.

Table 2 Monthly Wind Heading in the Direction of Tarkwa-Banso for the Year 2013

\begin{tabular}{|l|c|c|}
\hline \multicolumn{1}{|c|}{ Month } & $\begin{array}{c}\text { Mean Wind } \\
\text { Speed (m/s) }\end{array}$ & $\begin{array}{c}\text { Percentage of } \\
\text { Month (\%) }\end{array}$ \\
\hline January & 0.48 & 16.1 \\
\hline February & 0.40 & 7.1 \\
\hline March* & - & - \\
\hline April & 0.42 & 14.8 \\
\hline May & 0.40 & 11.7 \\
\hline June & 0.64 & 10.7 \\
\hline July & 0.47 & 5.2 \\
\hline August & 1.10 & 0.15 \\
\hline September & 1.23 & 0.5 \\
\hline October & 0.86 & 2.5 \\
\hline November & 0.43 & 11.1 \\
\hline December & 0.42 & 9.6 \\
\hline
\end{tabular}

*No recorded wind movement for the month

\subsection{Air Quality at GMC Site}

The monthly average $\mathrm{PM}_{10}$ and TSP concentration levels on GMC operational site for the year 2013 are shown in Fig. 4. The air pollutants concentration levels were comparatively highest for the months of January, February and December in the year 2013 .

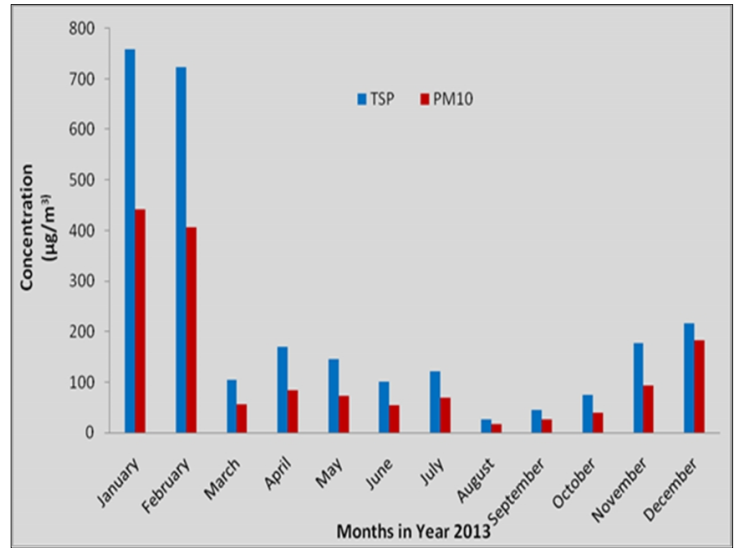

Fig. $4 \mathrm{PM}_{10}$ and TSP Conc. Levels on GMC Site for the year of 2013

\subsection{Air Quality in Tarkwa-Banso Community}

The monthly average $\mathrm{PM}_{10}$ and TSP concentrations measured in the Tarkwa-Banso community for the year 2013 are shown in Fig. 5. Airborne pollutants concentration levels in the Tarkwa-Banso community were below the respective Ghana EPA's permissible limits. The highest recorded TSP concentration was observed in July 2013, about 2.2\% below EPA's permissible limit of 150 $\mu \mathrm{g} / \mathrm{m}^{3}$. Also, the highest recorded $\mathrm{PM}_{10}$ concentration was observed in October 2013, about $7.4 \%$ below EPA's permissible limit of $70 \mu \mathrm{g} / \mathrm{m}^{3}$.

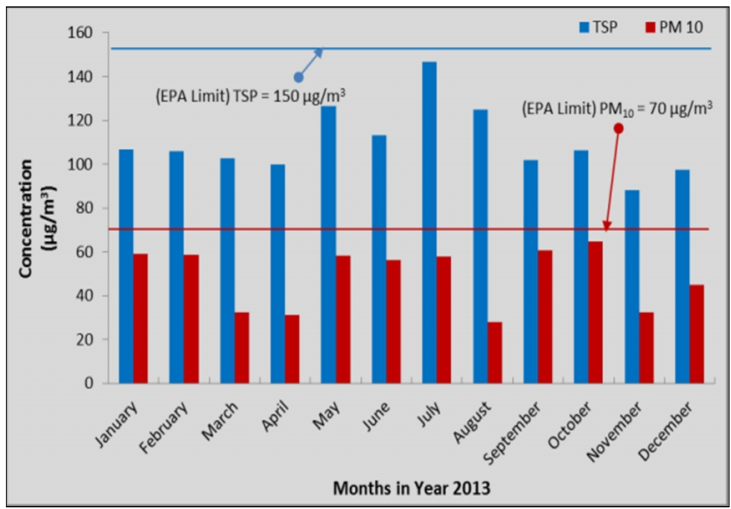

Fig. 5 TSP and $\mathrm{PM}_{10}$ Conc. Levels in TarkwaBanso for the year of 2013

\section{Resources and Methods Used}

\subsection{Pollutant Estimations and Emission Prediction Methods}

The main emissions from mining operations at the mine consist of wind-borne dust from overburden removal and storage, drilling, blasting, mining, rock transportation, crushing and sizing, and fugitive dust generated by vehicular movements in the open pits and along the haul roads. Other emissions are vehicle exhaust fumes. Air pollutants considered for this study and generated by GMC are basically airborne dust $\left(\mathrm{PM}_{10}\right.$ and TSP) and vehicle or mine machinery exhausts fumes $\left(\mathrm{SO}_{2}\right.$ and $\mathrm{NO}_{\mathrm{x}}$ ).

Taking note of the year round rainfall variation at GMC site, dust attenuation caused by forest cover and rainfall was estimated as $85 \%$, whilst attenuation of $90 \%$ was estimated for the effective working of the dust collector component on the drill rigs together with forest cover and rainfall.

The air pollutants concentration levels transmitted from GMC site to Tarkwa-Banso community were predicted at a referenced $400 \mathrm{~m}$ buffer from Pit C North. The predictions were based on available air monitoring data from stationary monitoring instruments mounted at the Crushing Plant (CP) using various types of models. The maximum recorded dust concentrations from these monitoring stations were used for the predictions.

The set of airborne pollutants obtained from the CP monitoring station on GMC site were used to predict pollutant concentrations at the $400 \mathrm{~m}$ buffer from the Pit $\mathrm{C}$ North towards Tarkwa-Banso 
community. Air pollutants emissions data (dust and exhaust fumes) estimated from the proposed mining equipment specified in the Mine's Environmental Impact Statements (GMC-EIS, 2012) were also used to predict concentrations at $400 \mathrm{~m}$ buffer from the Pit C North towards Tarkwa-Banso community.

\subsection{Models Used}

Three sets of models were adopted and used for the prediction and estimation of air pollutant concentrations at $400 \mathrm{~m}$ from Pit C North. The models are the Gaussian dispersion model, empirical emission estimation models by the United States Environmental Protection Agency (USEPA), and emission rates estimation adopted for similar mining projects as used by AMEC (2011).

\subsubsection{Gaussian Dispersion Models}

The Gaussian dispersion model for an elevated source at distance $H$ above ground level was used to predict dust levels at $400 \mathrm{~m}$ buffer using measured dust concentrations obtained at the CP monitoring station. This model (Rau and Wooten, 1980) is given in its reduced form as:

$$
\mathrm{C}_{j}(\mathrm{x}, \mathrm{y}, \mathrm{z})=\frac{\mathrm{Q}_{\mathrm{j}}}{2 \pi u \sigma_{y} \sigma_{z}}\left[2 \exp \left(-\frac{\mathrm{H}^{2}}{2 \sigma_{z}^{2}}\right)\right]
$$

where $C_{j(x, y, z)}=$ Concentration of species, $j$, at the predicted distance, $\mathrm{g} / \mathrm{m}^{3} ; \mathrm{Q}_{\mathrm{j}}=$ emission rate of pollutant, $\mathrm{j}$, emitted by the source, $\mathrm{g} / \mathrm{s} ; \sigma_{\mathrm{y}}=$ Gaussian coefficient for lateral dispersion, $\mathrm{m} ; \sigma_{\mathrm{z}}=$ Gaussian coefficient for vertical dispersion, $\mathrm{m} ; \mathrm{u}=$ average speed of specie; and $\mathrm{H}=$ stack height/emission height above ground.

The Gaussian coefficients, $\sigma_{\mathrm{y}}$ and $\sigma_{\mathrm{z}}$, were further determined from Martin's equations Boubel et al., (1994), thus:

$$
\begin{aligned}
& \sigma_{\mathrm{y}}=\mathrm{ax}{ }^{\mathrm{b}} \\
& \sigma_{\mathrm{z}}=\mathrm{cx} \mathrm{x}^{\mathrm{d}}+\mathrm{f}
\end{aligned}
$$

where a, b, c, d and f, are Martin's coefficients.

However, for estimated dust emissions and vehicular or mine machinery exhausts fumes, the Gaussian dispersion model for a point source at ground level was employed for the prediction of the concentrations. The Gaussian dispersion model for a ground level point source, used for the prediction is given by the expression:

$$
\mathrm{C}_{j}(\mathrm{x}, \mathrm{y}, \mathrm{z})=\frac{\mathrm{Q}_{\mathrm{j}}}{2 \pi u \sigma_{y} \sigma_{z}}
$$

where $\mathrm{C}_{\mathrm{j}(\mathrm{x}, \mathrm{y}, \mathrm{z})}=$ Concentration of species, $\mathrm{j}$ $\left(\mathrm{g} / \mathrm{m}^{3}\right)$, at the predicted distance; $\mathrm{Q}_{\mathrm{j}}=$ emission rate of pollutant, $\mathrm{j}$, emitted by the source, $\mathrm{g} / \mathrm{s} ; \sigma_{\mathrm{y}}=$ Gaussian coefficient for lateral dispersion, $\mathrm{m} ; \sigma_{\mathrm{z}}=$ Gaussian coefficient for vertical dispersion, $\mathrm{m}$; and $\mathrm{u}=$ average speed of specie.

\subsubsection{The USEPA Models}

The major operations of the Mine that greatly contribute to fugitive emissions include loading and unloading trucks (dumping), blasting operations, and drilling operations (USEPA, 1998; AMEC, 2011). The USEPA has generated equations for estimating the emissions of TSP and $\mathrm{PM}_{10}$ pollutant concentrations in metal mines. The USEPA equation for the estimation of TSP and $\mathrm{PM}_{10}$ during batch loading and unloading of a dump truck with an excavator in a metal mine is given as:

$$
E F_{T S P / P M_{10}}=k_{T S P / P M_{10}} \times 0.0016 \times \frac{\left(\frac{U}{2.2}\right)^{1.3}}{\left(\frac{M}{2}\right)^{1.4}}
$$

where $\mathrm{EF}_{\mathrm{TSP}}=$ emission factor for total suspended particles $(\mathrm{kg} / \mathrm{t}) ; \mathrm{EF}_{\mathrm{PM} 10}=$ emission factor for $\mathrm{PM}_{10}$ $(\mathrm{kg} / \mathrm{t}) ; \mathrm{k}_{\mathrm{TSP}}=0.74$ for particles less than $30 \mu \mathrm{m}$ aerodynamic diameter; $\mathrm{k}_{\mathrm{PM} 10}=0.35$ for particles less than $10 \mu \mathrm{m}$ aerodynamic diameter; $\mathrm{U}=$ mean wind speed $(\mathrm{m} / \mathrm{s})$; and $\mathrm{M}=$ moisture content $(\%$ by weight).

The USEPA equations for the estimation of $\mathrm{PM}_{10}$ and TSP during open pit blasting at a mine are given as:

$$
\begin{array}{r}
\mathrm{EF}_{\mathrm{PM}_{10}(\mathrm{~kg} / \text { blast })}=0.52 \times 0.00022 \times \mathrm{A}^{1.5} \\
\mathrm{EF}_{\mathrm{TSP}(\mathrm{kg} / \text { blast })}=0.00022 \times \mathrm{A}^{1.5}
\end{array}
$$

where $\mathrm{A}=$ the area blasted $\left(\mathrm{m}^{2}\right)$.

\subsubsection{Equipment Emission Rates}

In undertaking environmental assessment it is usual to adopt emission rates from known and reliable sources. AMEC (2011) used emission rates of major diesel powered mining machineries to estimate the $\mathrm{PM}_{10}, \mathrm{NO}_{\mathrm{X}}$ and $\mathrm{SO}_{2}$ concentrations of an open pit mine. The $\mathrm{PM}_{10}, \mathrm{NO}_{\mathrm{X}}$ and $\mathrm{SO}_{2}$ emission rates of the diesel powered machineries as used by AMEC are tabulated in Table 3. These emission rates were used to estimate dust concentrations generated from mining operations, and also from mine machinery exhausts.

\section{Results and Discussions}

\subsection{Dust Pollutants Predictions for Crushing Plant}


Measured dust pollutants on GMC site from January to December 2013 were used to predict concentration at the $400 \mathrm{~m}$ buffer from Pit C North in the direction of Tarkwa-Banso community. The Gaussian dispersion model for an elevated source was used for this prediction. The parameters used for the dispersion model have been given in Table 4.

Using a sampling rate of $600 \mathrm{cc} / \mathrm{min}$ for the Osiris Airborne Monitoring Instrument (Anon., 2014), the emission rate, $\mathrm{Q}_{\mathrm{j}}$, of the airborne pollutants was computed as $0.036 \mathrm{~m}^{3} / \mathrm{s}$. The projected maximum monthly prediction at the $400 \mathrm{~m}$ buffer from Pit C North for airborne pollutants heading towards Tarkwa-Banso from GMC site (as measured at the $\mathrm{CP}$ ) is shown in Fig. 6. In March, no wind movement was recorded.

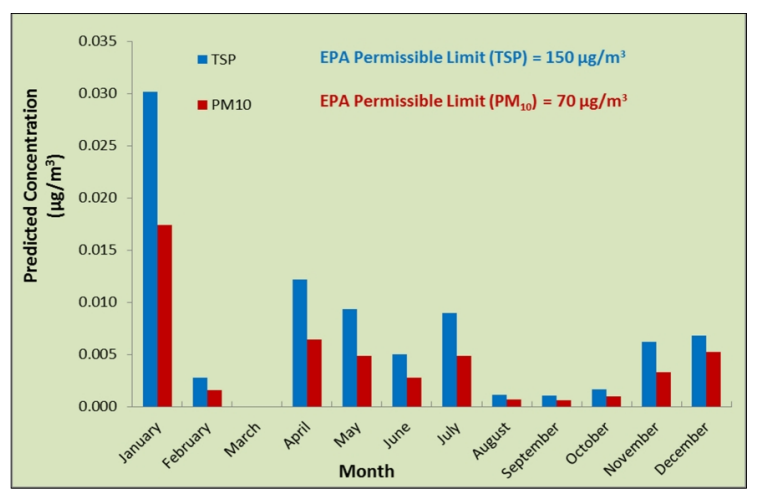

Fig. 6 Predicted Monthly $\mathrm{PM}_{10}$ and TSP Conc. from Crushing Plant

All the predicted monthly $\mathrm{PM}_{10}$ and TSP concentrations were far below the EPA permissible limit of $70 \mu \mathrm{g} / \mathrm{m}^{3}$ and $150 \mu \mathrm{g} / \mathrm{m}^{3}$ respectively. The maximum predicted monthly $\mathrm{PM}_{10}$ and TSP concentrations were observed in January as 0.0174 $\mu \mathrm{g} / \mathrm{m}^{3}$ and $0.0302 \mu \mathrm{g} / \mathrm{m}^{3}$ respectively. These maximum concentrations were about $99.98 \%$ below the respective EPA permissible limit.

In general, predicted monthly concentrations of the airborne particulates $\left(\mathrm{PM}_{10}\right.$ and TSP) from the crushing plant reaching the $400 \mathrm{~m}$ buffer were very much lower than the permissible regulatory requirement. This observation indicates that, generated dust pollution resulting from operating the crushing plant on GMC site would not impact Tarkwa-Banso community.

\subsection{Dust Emissions Estimation for Drilling Operations}

By using the meteorological data obtained from GMC site weather monitoring instrument, and the estimated dust attenuations, the dust emissions $\left(\mathrm{PM}_{10}\right)$ from drilling operations were estimated according to AMEC (2011) (Table 3); and the concentrations levels at $400 \mathrm{~m}$ from Pit C North were predicted using the Gaussian dispersion model (Eqn. 4). It may be noted that TSP levels are commonly far less than $\mathrm{PM}_{10}$ generation during drilling, hence the focus on $\mathrm{PM}_{10}$ concentrations. The monthly predicted concentrations of $\mathrm{PM}_{10}$ at the $400 \mathrm{~m}$ buffer from Pit C North for drilling operations in the pit as compared to the regulatory permissible limit for residential areas are shown in Fig. 7.

Table 3 Equipment Emission Rates (AMEC, 2011) and Equipment Used at GMC

\begin{tabular}{|l|c|c|c|c|}
\hline \multirow{2}{*}{ EQUIPMENT } & \multicolumn{2}{c|}{ EMISSION RATE (g/s) } & *No. of \\
Units
\end{tabular}

*GMC-EIS (2012) 
Table 4 Parameters Used for the Gaussian Model

\begin{tabular}{|c|c|c|c|c|c|c|c|c|c|}
\hline \multirow{2}{*}{$\begin{array}{c}\text { Monitoring } \\
\text { Station } \\
\text { Location }\end{array}$} & \multirow{2}{*}{$\begin{array}{c}\text { Height } \\
\text { (m) }\end{array}$} & \multirow{2}{*}{$\begin{array}{c}\text { Distance } \\
\text { to Buffer } \\
\quad(\mathbf{k m})\end{array}$} & \multicolumn{5}{|c|}{$\begin{array}{c}\text { *Corresponding Martin's Equation } \\
\text { Coefficients }\end{array}$} & \multicolumn{2}{|c|}{$\begin{array}{c}\text { Calculated Gaussian } \\
\text { Coefficients }\end{array}$} \\
\hline & & & a & $\mathbf{b}$ & c & D & $\mathbf{f}$ & $\sigma_{y}(m)$ & $\sigma_{\mathrm{z}}(\mathrm{m})$ \\
\hline $\begin{array}{l}\text { Carbonate } \\
\text { Plant (CP) }\end{array}$ & $\mathrm{H}=5.2$ & $\mathrm{x}=1.80$ & 50.5 & 0.894 & 55.4 & 0.305 & -34.0 & 84.409 & 32.278 \\
\hline
\end{tabular}

*Boubel et al., (1994)

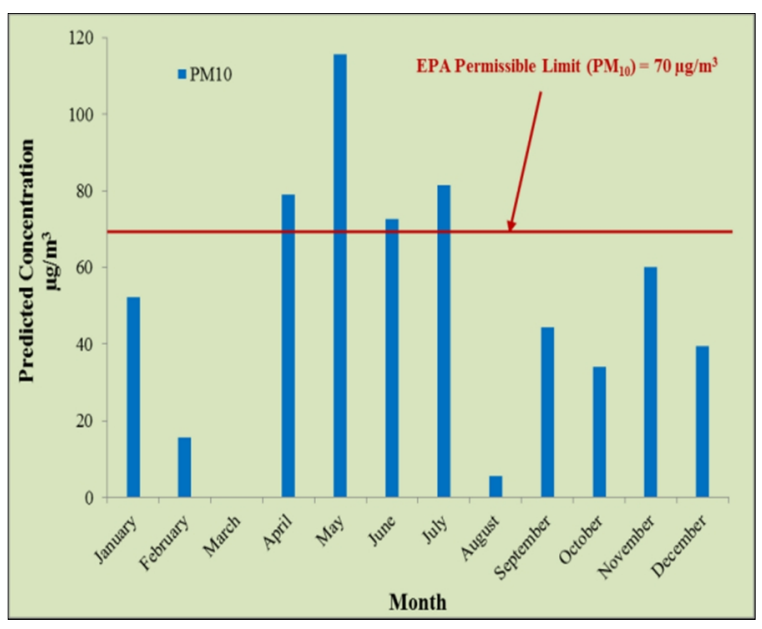

Fig. 7 Predicted Monthly $\mathbf{P M}_{10}$ Conc. for Drilling Operations at Pit C North

It is observed in Fig. 7 that drilling operations generally produce $\mathrm{PM}_{10}$ emissions lower than the regulatory requirement of $70 \mu \mathrm{g} / \mathrm{m}^{3}$ except the midyear months (April, May, June and July) which values were higher than the regulatory requirement in the order of $13 \%, 65 \%, 4 \%$ and $16 \%$ respectively. Again, no pollutant is predicted to reach Tarkwa-Banso in the month of March as a result of no wind movement heading from GMC to the community.

It may also be noted that the mid-year months record the highest rainfall amounts in the year round, and this together with the dust mitigation measures undertaken on the mine site should further reduce these predicted concentrations.

\subsection{Dust Emissions Estimation for Loading Operations}

The USEPA model for batch loading and unloading of a dump truck with an excavator in a mine (Eqn. 5) was used for the estimation of $\mathrm{PM}_{10}$ and TSP generated from loading operations at Pit C North. With the monthly mean wind speed on the mine, total monthly tonnes $(500,000 \mathrm{t})$ of material mined per GMC mining schedule (GMC-EIS, 2012), and the moisture content of the material being mined $[17.5-22.2 \%$ by weight according to Kuma, (2006)], the monthly $\mathrm{PM}_{10}$ and TSP concentrations in Pit $\mathrm{C}$ North were estimated. Using the Gaussian dispersion model (Eqn. 4), the estimated $\mathrm{PM}_{10}$ and TSP concentrations were predicted at the $400 \mathrm{~m}$ buffer from Pit C North. These predicted monthly pollutant concentrations as compared with the regulatory requirements are shown in Fig. 8.

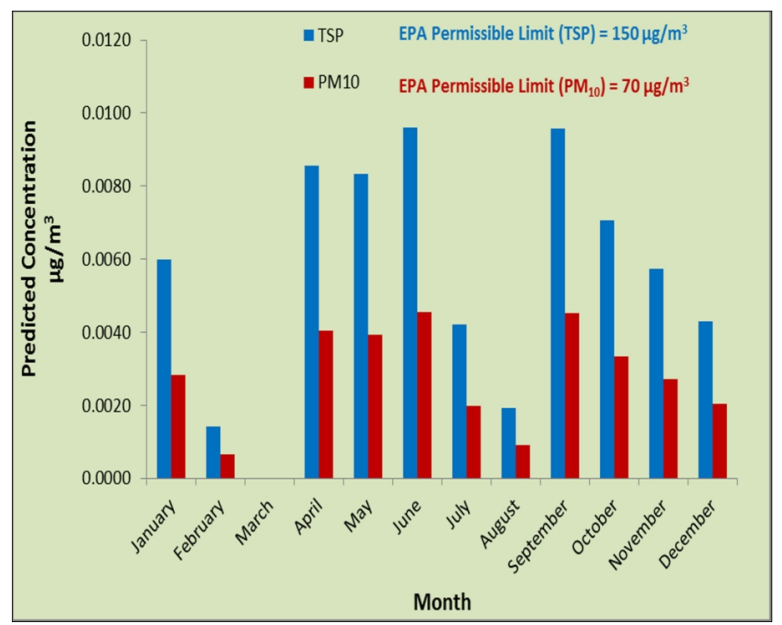

Fig. 8 Predicted Monthly $\mathbf{P M}_{10}$ and TSP Conc. for Loading Operations at Pit C North

\subsection{Dust Emissions Estimation for Blasting Operations}

It is observed in Fig. 8 that, all the predicted monthly concentrations of $\mathrm{PM}_{10}$ and TSP generated from batch loading and unloading operations at 400 $\mathrm{m}$ from Pit $\mathrm{C}$ North are well below the regulatory acceptable limits.

The USEPA models for blasting operations (Eqns. 6 and 7) were used to estimate the $\mathrm{PM}_{10}$ and TSP concentrations generated from blasting operations at the Pit C North. With committed total blast holes of 80 per shot, and designed blast pattern of $3.5 \mathrm{~m}$ by $4.0 \mathrm{~m}$ (GMC-EIS, 2012), the estimated $\mathrm{PM}_{10}$ and TSP dust concentrations per day (24-hour period) are respectively $0.0496 \mathrm{~g} / \mathrm{s}$ and $0.0954 \mathrm{~g} / \mathrm{s}$. The predicted monthly $\mathrm{PM}_{10}$ and TSP concentrations at the $400 \mathrm{~m}$ buffer from Pit C North using meteorological data on GMC site and the Gaussian dispersion model (Eqn. 4) compared to regulatory requirement are shown in Fig. 9. 


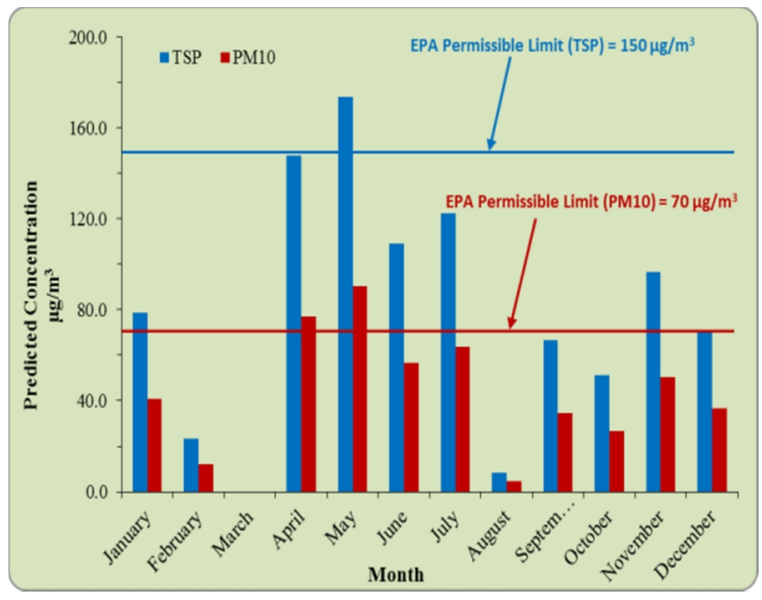

Fig. 9 Predicted Monthly $\mathrm{PM}_{10}$ and TSP Conc. for Blasting Operations at Pit C North

As shown in Fig. 9, all predicted monthly $\mathrm{PM}_{10}$ concentrations from blasting in Pit $\mathrm{C}$ North are relatively lower than the regulatory permissible limit of $70 \mu \mathrm{g} / \mathrm{m}^{3}$, with the exception of the months of April and May. The predicted $\mathrm{PM}_{10}$ concentrations for the months of April and May were respectively $10 \%$ and $30 \%$ greater than the allowable regulatory permissible limit.

The predicted monthly TSP concentrations at 400 $\mathrm{m}$ buffer from blasting in Pit $\mathrm{C}$ North were comparatively lower than the regulatory permissible limits of $150 \mu \mathrm{g} / \mathrm{m}^{3}$ with the exception of May. The predicted TSP concentrations for the month of May exceeded the allowable regulatory limits by $16 \%$.

Dust suppression practices undertaken in the pits before blasting should reduce further these predicted concentrations in all months to levels below the regulatory requirement.

\subsection{Emission Estimations from Vehicle Exhausts}

Vehicle exhaust emission $\left(\mathrm{NO}_{\mathrm{X}}\right.$ and $\left.\mathrm{SO}_{2}\right)$ rates of major mine machinery as used by AMEC (2011) together with the number of mining equipment to be used at Pit $\mathrm{C}$ North (Table 3) and on-site metrological information (Table 2) were used to predict the gaseous concentrations at $400 \mathrm{~m}$ buffer from Pit $\mathrm{C}$ North using the Gaussian dispersion model (Eqn. 4). The predicted monthly $\mathrm{NO}_{\mathrm{X}}$ and $\mathrm{SO}_{2}$ concentrations at $400 \mathrm{~m}$ from Pit $\mathrm{C}$ North compared to the regulatory permissible limits are shown in Fig. 10.

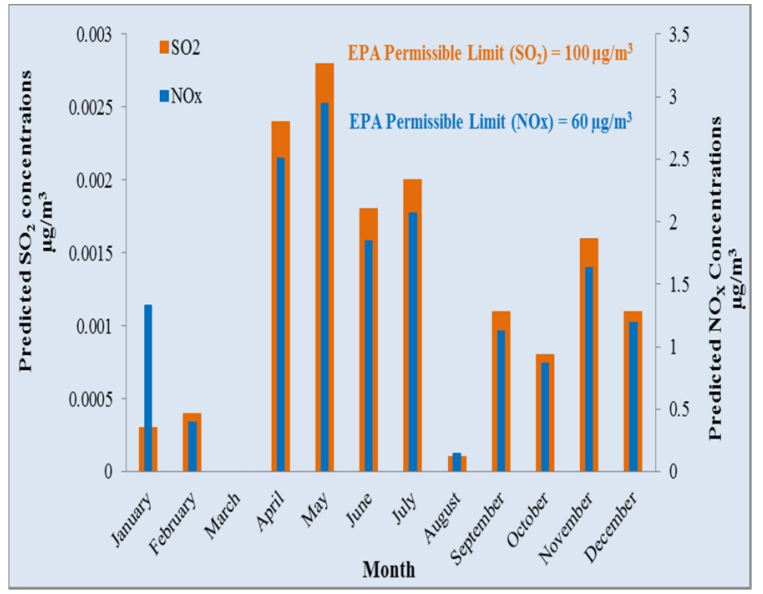

Fig. 10 Predicted Monthly $\mathrm{SO}_{2}$ and NOx Conc. from all Machinery in Operation at Pit $\mathrm{C}$ North

All the predicted monthly concentrations of $\mathrm{NO}_{\mathrm{X}}$ and $\mathrm{SO}_{2}$ at the $400 \mathrm{~m}$ buffer from Pit $\mathrm{C}$ North are significantly lower than the allowable regulatory limits of $60 \mu \mathrm{g} / \mathrm{m}^{3}$ and $100 \mu \mathrm{g} / \mathrm{m}^{3}$.All the predicted monthly concentrations of $\mathrm{NO}_{\mathrm{X}}$ at the $400 \mathrm{~m}$ buffer were below $3 \mu \mathrm{g} / \mathrm{m}^{3}$ whiles that for $\mathrm{SO}_{2}$ were also below $0.003 \mu \mathrm{g} / \mathrm{m}^{3}$.

\section{Conclusions}

The annual Windrose plot (Fig. 1) indicates that, about $8.0 \%$ of the period from January 2013 to December 2013, the wind blows with an average speed of $0.42 \mathrm{~m} / \mathrm{s}$ from GMC site towards the Tarkwa-Banso community. In the order of wind movement dominance towards Tarkwa-Banso community, the month of April recorded the highest value.

Dust level concentrations in the Tarkwa-Banso community were below the respective EPA's permissible limits. The highest recorded TSP concentration was observed in July 2013, about 2.2 $\%$ below the regulatory permissible requirement of $150 \mu \mathrm{g} / \mathrm{m}^{3}$ while the highest recorded $\mathrm{PM}_{10}$ concentration was observed in October 2013, about $7.4 \%$ below the regulatory permissibly limit of 70 $\mu \mathrm{g} / \mathrm{m}^{3}$.

All the predicted TSP concentrations were below the EPA permissible limit of $150 \mu \mathrm{g} / \mathrm{m}^{3}$. The maximum monthly predicted TSP concentration was observed in January as $0.0302 \mu \mathrm{g} / \mathrm{m}^{3}$, about $99.98 \%$ below the EPA permissible limit. The maximum monthly predicted $\mathrm{PM}_{10}$ concentration was noted in January to be $0.0174 \mu \mathrm{g} / \mathrm{m}^{3}$, about $99.98 \%$ below the EPA permissible limit. The predicted monthly concentrations of the airborne particulates $\left(\mathrm{PM}_{10}\right.$ and $\left.\mathrm{TSP}\right)$ from the crushing plant at the $400 \mathrm{~m}$ buffer were lower than the permissible regulatory requirement. This indicates that, the operating of the crushing plant on GMC site has no impact to Tarkwa-Banso community. 
Drilling activity generally produces emissions lower than the regulatory requirement except the mid-year months (April, May, June and July) which values were higher than the regulatory requirement. All the predicted $\mathrm{PM}_{10}$ and TSP dust concentrations according to USEPA model generated from loading and unloading activity in Pit C North are lower than the regulatory acceptable limits. All the predicted monthly TSP concentrations from blasting activity in Pit C North at the $400 \mathrm{~m}$ buffer are comparatively lower than the regulatory permissible limit of $150 \mu \mathrm{g} / \mathrm{m}^{3}$ except for the month of May. All monthly predicted $\mathrm{PM}_{10}$ concentrations from blasting activity at $400 \mathrm{~m}$ from Pit $\mathrm{C}$ North were relatively lower than the regulatory permissible limit of 70 $\mu \mathrm{g} / \mathrm{m}^{3}$ with the exception of the months of April and May.

Therefore, the concentrations of TSP, $\mathrm{PM}_{10}$, NOx and $\mathrm{SO}_{2}$ air pollutants beyond the $400 \mathrm{~m}$ from the crest of Pit C North into Tarkwa-Banso community will meet the Air Quality Guidelines defined by the Ghana EPA.

\section{References}

AMEC (2011), "Atmospheric Environment Emission Sources and Air Quality Modelling”, Unpublished Report, AMEC Earth and Environment, Version 1.0, Avanti Mining Inc., Kitsault Mine Project, Canada, 37 pp.

Amegbey, N. and Afum, B. O. (2014), "Atmospheric Pollutants Diffusion Studies", Unpublished Report, Ghana Manganese Company, Tarkwa, 48 pp.

Amegbey, N. and Afum, B. O. (2015), "Blast Impact Prediction Studies at Ghana Manganese Company (GMC) Ltd, Nsuta, Ghana", Ghana Mining Journal, Vol. 15, No. 1, pp. 73-77.

Anon., (2014), Osiris Operating Instruction, Turnkey Instruments Ltd, United Kingdom, 42 pp.

Boubel, R. K., Fox, D. L., Turner, D. B. and Stern, A. C. (1994), Fundamentals of Air Pollution, Academic Press, $3^{\text {rd }}$ Edition, California, USA, 574 pp.

GMC-EIS (2012), "Environmental Impact Statement (EIS) for the Proposed Pit C North Project, Ghana Manganese Company (GMC)", Unpublished Report, Ghana Manganese Company, Tarkwa, $126 \mathrm{pp}$.

Kuma J. S. (2006), "Hydrogeological studies on the Tarkwa gold mining district, Ghana", Bulletin of Engineering Geology and the Environment, Volume 66, Issue 1, pp. 89-99.

Rau, G. R. and Wooten D. C. (1980), Environmental Impact Analysis Handbook, MacGraw Hill Book Company, Wooten D. C. (Editors), USA, 642 pp.

USEPA (1998), Compilation of Air Pollutant Emission Factors, Volume I: Stationary Point

and Area Sources, $5^{\text {th }}$ Edition. Office of Air Quality Planning and Standards, U. S. Environmental Protection Agency, Research Triangle Park, North Carolina, 697 pp.

\section{Author}

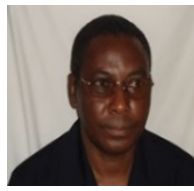

Newton Amegbey is a Professor in Mining, Mine Environment and Safety Engineering in the University of Mines and Technology (UMaT). He holds MSc from the Mining Institute of Petrosani, Romania, $\mathrm{PhD}$ from the Technical University of Berlin, West Germany, in 1987. He is a fellow of the Mine Ventilation Society for South Africa, member of the German Society of Mining and Metallurgy, and member of the Society of Mining, Metallurgy and Exploration (MSME). His research areas include health and safety in the mine, mine ventilation, environmental impact predictions, and mining regulations.

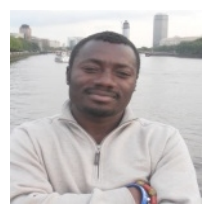

Bright Oppong Afum is a Lecturer in the Mining Engineering Department of the University of Mines and Technology (UMaT). He holds BSc Mining Engineering Degree from Kwame Nkrumah University of Science and Technology (KNUST), and MSc Environmental Monitoring and Analysis Degree from the Aberystwyth University (AU), United Kingdom. He is currently a PhD Researcher at UMaT. He is a member of the Society of Mining, Metallurgy and Exploration (MSME), member of the Australasian Institute of Mining and Metallurgy (MAusIMM), and a graduate member of the Ghana Institution of Engineers (GMGhIE). His research areas include operations research, environmental geochemistry and impact studies, explosives and blasting technology, and mine planning and design.

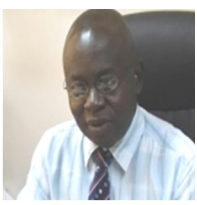

Samuel A Ndur is a Senior Lecturer at the University of Mines and Technology (UMaT), Tarkwa. He holds PhD (Environmental Geochemistry) from New Mexico Institute of Mining and Technology, USA, and MSc (Petrochemical Engineering) from Moscow Institute of Oil and Gas, CIS. $\mathrm{He}$ is a member of Society of Environmental Geochemistry and Health (SEGH), and International Association of Impact Assessments (IAIA). His research areas are Environmental Pollution and Control, Mine Waste Characterization and Management, Arsenic Sequestration, and Water Quality Issues.

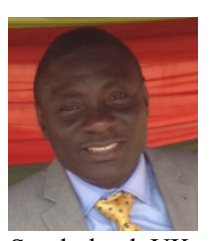

Sunderland, UK.
Rev. Emmanuel Coffie-Anum is the Environmental Coordinator of GMC Ltd. with a core responsibility of environmental strategic planning and monitoring in the Environmental Department. He holds MSc Environmental Management and Assessment degree from the University of 